\title{
Heuristic Evaluation of Serious Game Application for Slow-reading Students
}

\author{
Saffa Raihan Zainal Abidin ${ }^{1}$, Siti Fadzilah Mat Noor ${ }^{2}$, Noraidah Sahari Ashaari ${ }^{3}$ \\ Faculty of Information Science \& Technology, Universiti Kebangsaan Malaysia, Bangi, Malaysia
}

\begin{abstract}
The findings of preliminary studies found that conventional approaches were still relevant but students showed weak and moderate interest and quickly lost focus rather than technology approaches such as serious games were used especially for slow reading students (SRS). Most teachers use interventions that are not specifically designed to help SRS. They usually use teaching aids below the literacy level of the SRS. Therefore, an easy and user-friendly games application called "Mari Membaca" or M2M was developed. The objective is to make sure the application is free from design and interface problems by demonstrating the application of expert-based usability evaluation techniques such as Heuristic evaluation. This paper reports the experimental heuristic evaluation of M2M for SRS among expert evaluators includes remedial teachers and game developers. This study adopted ten Usability Heuristics and seven brain-compatible instructional phases of brain-based learning to be included in the questionnaire. The overall result derived from the evaluation is 14 out of 17 (3.41-5.00) above average mean score, which are neutral (2.61-3.40) in one domain. Several comments and feedback from the experts were essentials for further improvement of the game application to ensure meets the user requirement and expectation.
\end{abstract}

Keywords-Serious game; brain-based learning; heuristic evaluation; literacy skills; slow-reading students

\section{INTRODUCTION}

Struggles in reading can cause difficulties in all subject areas. Mastery in reading skills can influence in the progress or failure in daily performance especially in the examination [1]-[3]. Reading is a skill that requires several abilities (comprehension, visual and auditory processing) working together to be able to master. If a child is weak in any of those abilities, it can impact the ability to read [4]. A slow-reading student (SRS) is one of the most problematic learning problems since reading is the most crucial principle in learning. A "slow learner" is not a diagnostic category; they may have ordinary lives outside of the classroom. However, academic subjects are a challenge for them. SRS is lack in understanding compare to their peers but they do has their own ability to learn academic skills [5]. They are slightly different from their peers in terms of potential which they are struggling to meet the academic demands in normal class. Cognitive abilities, levels of understanding and thinking may differ slightly from other students, but still they are categorized as normal students [6], [7] because they still able to learn the learning skills [8]. Author in [9] state as well as having low cognitive, they also have memory and weak concentration and can hardly describe their ideas. SRS has limited capabilities when it involves symbols and abstracts such as language, numbers and concepts. They need more stimuli, encouragement, time and attention as well as technology and aid tools to help them in learning. The use of games in teaching and learning (T\&L) is increasingly gaining attention by teachers. The use of this medium is seen as an intervention tool to help SRS master the reading skills.

Serious games are an innovative teaching method that can enhance learning and entertainment to meet the needs of different children, especially students who are left behind in learning. Author in [10] refer the word 'serious' as the function of the game in delivering input in the form of education or training to players. Author in [11] stated that serious game was referred to as an entertainment tool with educational goals, in which the player fostered knowledge and practiced their skills while playing. In [12], a serious game designed that is interactive and has educational goals on any digital platform that created an active learning environment. In addition to the game intervention used, regular strategies are also important for achieving goals. The strategy covers aspects such as methods, techniques and approaches used.

There is a very different approach in learning to help educators today in evaluating, teaching and curriculum planning [13], which is brain-based learning (BBL) approach [14], [15]. In this serious game, the integration of the BBL approach is seen as an intervention in $T \& L$ to help students optimize the brain use and stay focused on learning. According to [16], BBL give a positive impact on student achievement because BBL focuses on brain function. The function of the brain can be fully optimized by the help of teachers and teaching aids using the liked and comfortable approach to enhance the individual self-potential. The most approach liked by students is the game [17]. The use of this BBL approach is selected as most have been applied indirectly by teachers in T\&L. As a result, a serious game compatible brain-based learning has developed. The objective is to obtain feedback and usability from expert by conduct a heuristic evaluation on game application or well known as M2M. Second subtopic will discuss on related work regarding this paper. Third, briefly describe about usability evaluation and advantage using heuristic evaluation. Fourth, explain the method use on this paper. Fifth, show the results and discussion about it. Lastly, conclusion and future work that can be expand from this paper.

\section{RELATED WORK}

In this section, brain-based learning (BBL) and implementation of BBL in serious game will discuss as it the main key themes in this study. 


\section{A. Brain-Based Learning (BBL)}

$\mathrm{BBL}$ is a technique of neurological and cognitive science studies that are used to improve teacher teaching. This approach was introduced three or four decades ago through a study revolution on the brain to help educators in planning, evaluating, teaching and curriculum [13]. In order to ensure the effectiveness of individual learning, this teaching approach is designed to fit the structure, tendency and optimum function of the human brain. Unlike conventional learning, this theory approach is based on every human being can learn as long as their brains do not forbid such routine processes[14], [15].

In [16] has implemented a BBL strategy based on twelve BBL principles developed by [14] through three teaching techniques related to this principle. According to [18], BBL has three closely related elements:

1) Relaxed alertness: Eliminates doubts within the student while maintaining a challenging learning environment. In this context, the provision of a less threatening environment but a challenge is through a serious game. Students are happy and comfortable to learn while playing the activities and exercises provided.

2) Orchestrated immersion: Creating a learning environment that gives students a meaningful experience. In this context involves the integration of learning experiences based on the student's tendency (play).

3) Active processing: Allows the student to unify and understand the information received [14]. In this context, active processing leads to serious game training and activities that encourage students to connect and deepen active knowledge.

BBL also affects students' academic achievement. Authors in [19], [20] stated that BBL can accelerate the process of thinking, planning and implementation processes that enhance the concept of understanding and motivation in learning. In Malaysia there are several studies using the BBL approach. Among them are [19] stated that the use of BBL method in learning can enhance the students' knowledge in the electric concept. Based on the study conducted by [21], brain-based teaching has improved the understanding of the students about the concept of Newton's Physics than traditional methods. Improve student understanding of concept and mechanism of photosynthesis [18]. The BBL method emphasizes active learning that can stimulate the brain which can help thinking skills, reduce stress and improve learning. Integration of BBL strategy in a serious game is expected to help improve SRS literacy skills while maintaining student motivation to continue learning.

\section{B. Implementation of Brain-Based Learning in Serious Game}

The basic difference between learning goals and game goals is learning goals are the intellectual knowledge and skills we want students to learn in the game, while the goal of the game is when players can complete all activities in the game [22]. So, when designing a serious game, designers need to consider how learning goals can interact with the goals of the game and how other approaches support this goal. Intervention of BBL approach in games is seen to be able to help slow-reading students (SRS) improve their understanding and motivation in T\&L. In this study, students are need to complete three situations which are i) fun learning (serious games), ii) learning using their syllabus and in relation to prior knowledge iii) actively involved in all seven phases of braincompatible teaching by [23]. The seven phases of the teaching are:

1) Activation: Serious game content developed should be able to activate the memory and early learning of the students by involving their syllabus to stimulate the transmission of information.

2) Clarify the outcomes that need to be achieved and the learning process involved: The objective of the game's learning is shown before the player starts a game session. This is to give an overview of the ideas taught and enable students to reinforce the learning target and activate the right brain and the left brain and eliminate anxiety in the student.

3) Making connection: Activities linking prior knowledge are an important in this approach. This process stimulates the brain to make connections based on student understanding to integrate new information with the existing one.

4) Carry out learning activities: This activity requires a thorough involvement by each student in every activity and allows students to digest, think, reflect, and look for the logical experience gained in visual, audio and kinesthetic in the game.

5) Demonstrating student's understanding: Students can test their understanding of involving the review process and repeating the newly acquired knowledge or skills and encouraging the transfer of information to the student's longterm memory system.

6) Review for students' retention: Activity in this game is an assessment to test and assess their understanding and acceptance of new concepts.

7) Preview next topic: The main menu featuring the topics learned provides the brain to prepare and help the brain to focus on learning in the next learning session.

According [18] stated that interactions between BBL principles elements were relax alertness, Orchestrated Immersion and active processing with brain-compatible teaching phases were seen to stimulate the learning motivation to create more effective learning. In [16], students' exposure to brain-based teaching strategies has helped students to focus more on learning and ability to achieve the highest level of learning. Teaching strategies that involve auditory, visual and kinesthetic provide space for students to maximize their learning abilities to improve learning outcomes.

\section{USABILITY EVALUATION}

The successful interactive software application depends on usability which is an important factor for all software quality models. A technique that is frequently used in the field of Human-computer Interaction is usability evaluation. To ensure game acceptance and positive reviews from players, game usability should be emphasized. Usability is important in game development as well, as it optimizes player engagement 
and accomplishment of individual and organizational objectives [24]. Some of the best-known usability models are those of the International Organization for Standardization [25]. This ISO are produced by international groups of experts after a careful review process. The definition of usability essentially consists of: 1) Effectiveness. 2) Efficiency, 3) Satisfaction.

Author in [26] state that using this evaluation it can help researcher to find a problems and provide suggestions to improve the system. A good user interface design typically needs the use of a variety of usability evaluation methods [27], [28]. Heuristic evaluation is an inspection method that appears frequently in the literature and experts preferred used it to determine usability problem in any application or product [29], [30].

Based on this study, researcher had chosen heuristic evaluation. Heuristic assessment is a software usability assessment tool that is widely used in the industry because it does not require much infrastructure, time and cost [32]-[34].

\section{A. Heuristic Evaluation}

Heuristic assessment is a usability inspection technique developed by [31], [35]. According [36], most of the research which is $60 \%$ of cases used Nielsen as the benchmark. According to [37], heuristic evaluation (HE) techniques previously used in software evaluation (systems and products) have now appeared in popular applications of games. Heuristic assessments are carried out by expert evaluation groups rather than actual users. Potential usability problems are grouped in a usability report. According to [38], most heuristic assessments are informal but their advantages are fast because assessed by experts, do not require high cost and efficient [38]-[43] and are suitable for use in every phase of the software cycle phase even after system execution [40]. HE does not need a fully functional prototype.

In the context of this study, teachers and game developers become evaluator in the assessment process. This is because the teacher's expertise in assessing the appropriate game content and the developer's expertise in evaluating the appropriate game elements. They examined a user interface and judge for compliance with recognized usability principles called "heuristics". The Heuristic Evaluation process can be separated in three major phases: An inspection phase, in which evaluators independently evaluate the user interface; a preparation phase where evaluators independently prepare their list of identified problems for aggregation; and an aggregation phase, in which evaluators together collaborate to generate a single report of usability problems. The lists of potential usability problems then are analyzed by researcher to agree and work on the usability problem fixes and priorities. Fig. 1 depicts the overall Heuristic Evaluation process.

\section{METHOD}

This study used heuristic evaluation to determine which problems in the interface of M2M tool that not suit to SRS. The result is used to enhance design better than before. Selected specialists were participating in the evaluation to identify the usability problems.

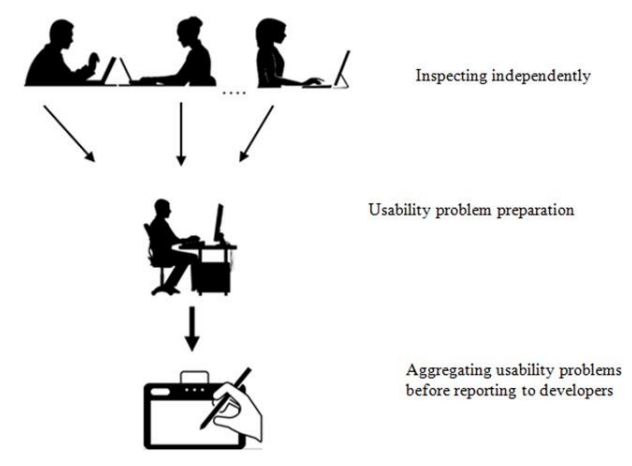

Fig. 1. Heuristic Evaluation Overview.

\section{A. Sample of Study}

For the total number of evaluators, usually 5 [44], [45] up to 8 assessors [46] are used in heuristic assessments. Seven specialists were involved that were selected based on the qualification and experience related to slow-reading students (SRS) and development of games. Table I shows the profile of expert evaluators.

\section{B. Research Instrument}

The instruments use to conduct this study include:

1) Questionnaire: Heuristic evaluation was used as a basis in the questionnaire for the evaluation of M2M. To perform a heuristic evaluation, it is necessary to adopt a list of principles to Heuristic evaluation was used as a basis in the questionnaire for the evaluation of M2M. To perform a heuristic evaluation, it is necessary to adopt a list of principles to guide the inspection. To evaluate the interface design, the following is the set of usability principles (Nielsen, 1994), which was used in this research. The questionnaire made up of three (3) sections: (A) Demographic, (B) Usability Heuristic for User Interface Design - which used the traditional Nielsen's heuristics and (C) BBL Heuristic - which embrace the twelve BBL principles developed by [14], through three teaching related to this principle that are considered techniques related to this principle that are considered essential for effective learning. The heuristic for game application is showed in Appendix A and B.

TABLE I. PROFILE OF EVALUATOR

\begin{tabular}{|l|l|l|l|}
\hline \multirow{2}{*}{ Evaluator } & \multirow{2}{*}{$\begin{array}{l}\text { Professional } \\
\text { Role }\end{array}$} & \multicolumn{2}{|l|}{ User Experience (Years) } \\
\cline { 3 - 4 } & & $\begin{array}{l}\text { Slow-reading } \\
\text { Students }\end{array}$ & Games \\
\hline 1 & Teacher & 6 & - \\
\hline 2 & Teacher & 9 & - \\
\hline 3 & Teacher & 12 & - \\
\hline 4 & Teacher & 7 & - \\
\hline 5 & Teacher & 5 & - \\
\hline 6 & Game developer & - & 3 \\
\hline 7 & Game developer & - & 5 \\
\hline
\end{tabular}


2) Hardware and software: Hardware used for the development of this tool was notebook and mouse. While, software used is Unity as a main authoring tool, Adobe Photoshop CS4 for graphic editing and Audacity for audio recording and editing.

3) Game application (M2M application): $\mathrm{M} 2 \mathrm{M}$ is a computer based and stand-alone application. It consists of five modules; "Huruf", "Suku Kata Terbuka", "Perkataan", "Ayat Mudah" dan "Cerita \& Lagu". Fig. 2 to 6 shows the main screenshots of the apps.

Fig. 2 shows a screenshot for main menu that displays each module available in this application. The user can click on any module to begin the application but for the first time user, teacher will guide to start with first module which is "Huruf" and so on. First module, users are required to completed two activities: i) Connecting the dot letters 'a' to ' $z$ ', and ii) Listening to phonic audio for the letters.

Fig. 3 shows a screenshot for the "Suku Kata Terbuka" menu. For each module chosen by the user, they will be shown with learning objectives before starting the game to give the user an overview of the game objective. Two activities involved; "Tarik \& Letak" and "Pusing \& Padan".

Fig. 4 shows a screenshot for the "Suku Kata Terbuka" menu. In this first activity "Tarik \& Letak", user needs to choose the correct syllable to form a word from options provided by drag on it and drop into box. Picture is provided to give an idea to user.

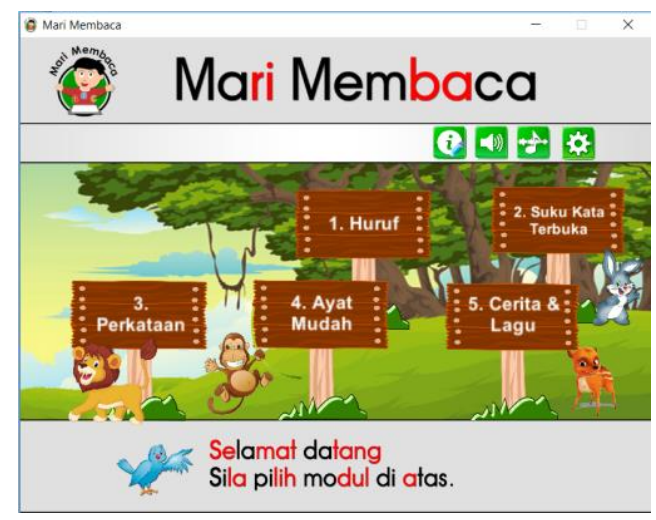

Fig. 2. Main Menu of M2M Game Application.

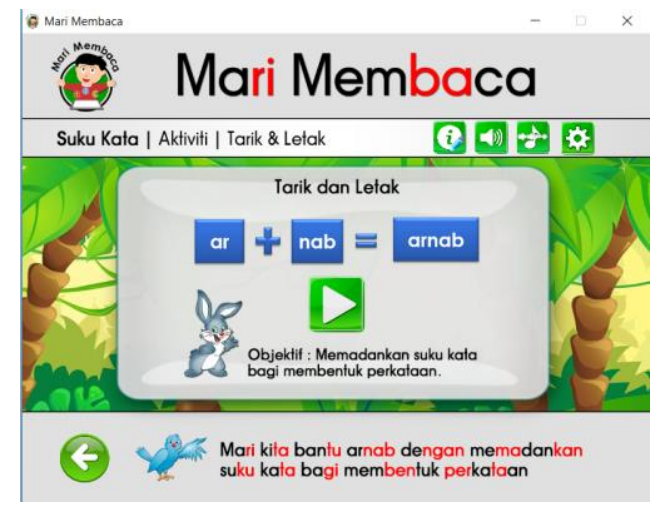

Fig. 3. The Objectives will be Preview on the Front of the Module.

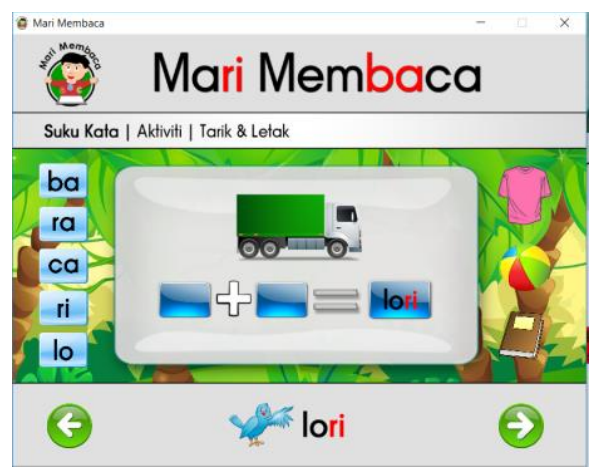

Fig. 4. Menu of "Suku Kata Terbuka".

Fig. 5 shows a screenshot for the "Frasa Perkataan" menu. In this activity, user needs to choose the correct words based on the picture given. User must select the answer from options provided by drag on it and drop into box. Picture is provided to give an idea to user.

Fig. 6 shows a screenshot for the "Ayat Mudah" menu. In this activity, user needs to choose the correct words based on the picture given. User must select the answer from options provided by drag on it and drop into box. Picture is provided to give an idea to user.

\section{Evaluation Process}

Heuristic evaluation of M2M application was conducted through offline activities where the apps were installed in the researcher laptop. The procedure of the evaluation consists of following steps as follows:

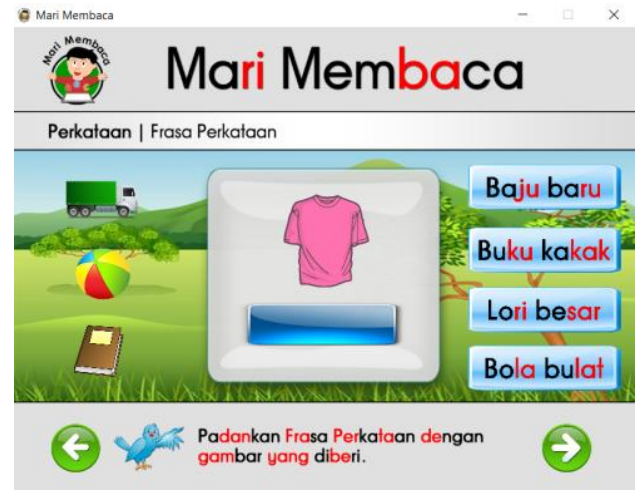

Fig. 5. Menu of "Frasa Perkataan".

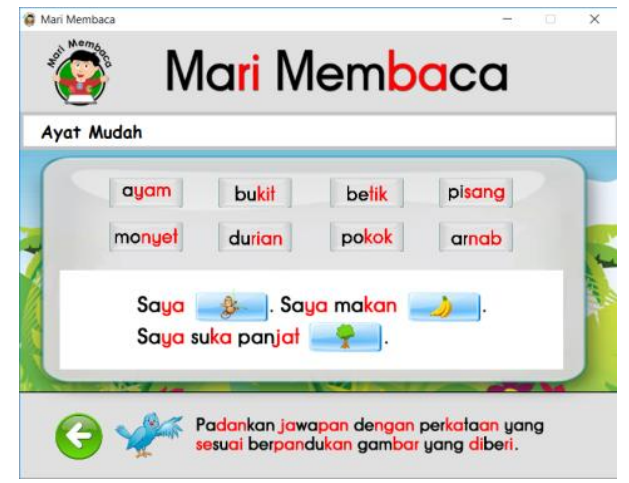

Fig. 6. Menu of "Ayat Mudah". 
1) Offline invitation: For teacher, researcher applied for permission from the Ministry of Education (MOE) to conduct the study. After the MOE issued a letter, the researcher requested the permission from the Labuan Federal Territory Education Department and then applied for the permission of the school. Researcher set a date with the experts for the evaluation and on that day the explanation of the evaluation purposes was given. For game developer, researcher set a date with the experts via call and on that day the explanation of the evaluation purposes was given.

2) Demonstration of the application: The researcher demonstrates the operational of application and after that the experts can use the apps. Next, the questionnaire was given to the experts.

3) Feedback: The specialist evaluated the application based on the provided questionnaire. Each participants answered a total of 17 questions based on a 5-Likert Scale (1 strongly Disagree, 2 - Disagree, 3 - Neutral, 4 - Agree, 5 Strongly Agree). Then, the questionnaire was collected. The specialist gave suggestions to deal the problems and also comments in order to improve the apps. Once the evaluation process completed, the data were analyzed accordingly.

\section{RESUlt AND DISCUSSION}

\section{A. Heuristic Evaluation Result}

Fig. 7 shows the mean score of the result from questionnaire analysis. Overall, the result indicate that the respondents agree and neutral on the heuristics criteria.

The results showed that, according to the respondents, the apps got acceptable rating in most aspect covered by game heuristic. For game heuristic, "INT 5: Error prevention" has 4.86 mean score which is the highest rating. Second highest is "INT 8: Aesthetic and minimalist design" by 4.57. Third highest are "INT 4: Consistently and standards" and "INT 9: Help users recognition, diagnose and recover from errors" which are 4.43 and followed by "Q1: Visibility of system status" and "Q2: Match between system and real world" obtained a score 4.29. The "INT 6: Recognition rather than recall" had mean score 3.86 individually. These heuristics have mean score more than 3.41 , which means that users were between agree and strongly agree with these six usability heuristic of the apps.

The "Q3: User control and freedom" obtained a neutral score which is 3.00. User are able to undo mistakes by given two chances but user not able to exit locations and if customer want to exit they need to exit apps. Meanwhile, heuristic "INT 7: Flexibility and efficiency of use" obtained a mean score 2.14 and "INT 10: Help and documentation" obtained a mean score 1.57 which is the lowest score and users were strongly disagree with these two heuristics off the apps. This app does not allow experienced users to use shortcuts and adjust setting yet as this low-fidelity prototype not complete yet. This prototype also doesn't provides appropriate online help as this apps is offline mode and documentation to make user easily accesses are not provide as this apps is for SRS which is they are weak in literacy. They will be guide by teacher.

For BBL heuristic, the results showed that, according to the respondents, the application got acceptable and had a particularly good rating in all aspect.

For game heuristic, "INT 2: Clarify the outcomes that need to be achieved and the learning process involved" has 4.86 mean score which is the highest rating. Second highest of the mean score is "INT 1: Activation" by 4.43. Third highest of the mean score is "INT 7: Preview the next topic" by 4.23 . Meanwhile, heuristic for "IN4: Carry out learning activities" and "INT 5: Demonstrating student's understanding" had mean score 4.00 individually. Both the "INT 3: Making connection" and "INT 6: Review for students' retention" had mean score 3.71. These heuristics have mean score more than 3.41 , which means that users were between agree and strongly agree with these six approaches of BBL heuristic of the apps.

Overall, the findings from the questionnaire were positive even though some of game heuristic received neutral score and two had negative from the experts. While the approach that applied seven phase compatible brain receive all positive feedback. Obviously, certain aspects of the M2M apps need to be improve based on the score of usability heuristic to ensure the apps is ready to be commercialized soon.

\section{B. Feedback and Comments from Expert}

Apart from the observations from the analysed data, the participants also give the feedback and commented on some advantages and weaknesses noticed in the games. The feedback and comments are as follows in Table II:

The comments of the teacher users focused more on the content that will make sure it suits the SRS level. While the comments from game developers are to improve the graphic user interface of the system for enhancement of features that will make the system complete.

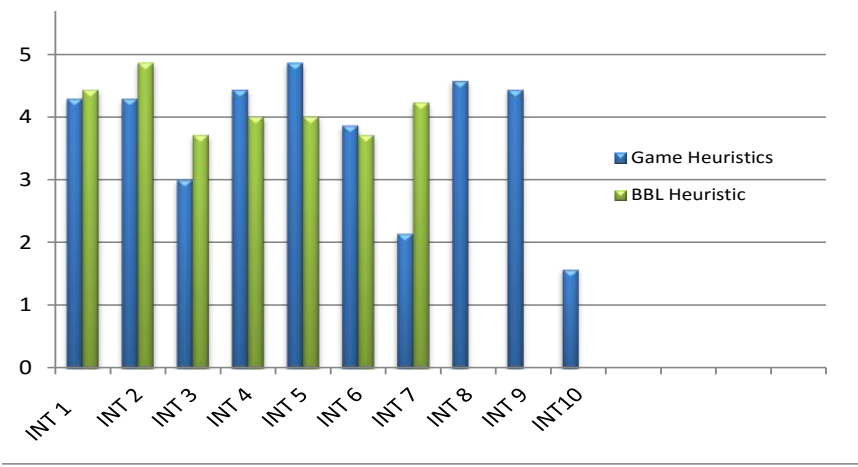

Fig. 7. Mean Score of the Questionnaire Analysis. 
TABLE II. FEEDBACK AND COMMENTS

\begin{tabular}{|c|c|c|}
\hline No. & Feedback/ Comments & Action to be Taken \\
\hline 1. & $\begin{array}{l}\text { The aesthetics of the games application in } \\
\text { terms of colour blend and appearance are } \\
\text { attractive as using a bright color. }\end{array}$ & $\begin{array}{l}\text { Using bright and contras } \\
\text { color to attract SRS } \\
\text { attention. }\end{array}$ \\
\hline 2. & $\begin{array}{l}\text { In activity "Tarik \& Letak" in module } \\
\text { "Suku Kata Terbuka" the number of the } \\
\text { questions is suitable for SRS level and } \\
\text { animation need to be reduce because it } \\
\text { may disrupt SRS attention. }\end{array}$ & $\begin{array}{l}\text { It follows BBL strategy } \\
\text { that for one activity the } \\
\text { max time to be } \\
\text { completed by SRS is } \\
\text { around } 9-12 \text { min. } \\
\text { Animation for this } \\
\text { module will be deleted. }\end{array}$ \\
\hline 3. & $\begin{array}{l}\text { For font in this app, Times New Roman is } \\
\text { not suitable for SRS. Experts (Teacher) } \\
\text { give a list of font name that suitable for } \\
\text { SRS. }\end{array}$ & $\begin{array}{l}\text { The font list that will use } \\
\text { is Waknan font. }\end{array}$ \\
\hline 4. & $\begin{array}{l}\text { The game apps need to be more user- } \\
\text { friendly. User is able to exit the game } \\
\text { without going back to main menu. }\end{array}$ & $\begin{array}{l}\text { Add exit button in game } \\
\text { setting. }\end{array}$ \\
\hline 5. & $\begin{array}{l}\text { The experts suggest that the proper time to } \\
\text { implement the game for SRS is at the first } \\
\text { quarter of year. }\end{array}$ & $\begin{array}{l}\text { Researcher will start the } \\
\text { testing on April } 2019 \text { as } \\
\text { per suggest. }\end{array}$ \\
\hline 6. & $\begin{array}{l}\text { It should be possible to access help in a } \\
\text { very easy way. }\end{array}$ & $\begin{array}{l}\text { Hint will be given after } \\
\text { two tries. }\end{array}$ \\
\hline 7. & $\begin{array}{l}\text { This apps is new approach to help SRS in } \\
\text { literacy using computer based application } \\
\text { and use multimedia elements (audio, } \\
\text { graphic), and BBL approaches which is } \\
\text { very attractive and suitable to SRS. }\end{array}$ & $\begin{array}{l}\text { Combine the entire } \\
\text { multimedia element } \\
\text { together with BBL } \\
\text { strategies. }\end{array}$ \\
\hline 8. & $\begin{array}{l}\text { The games is easy to learn and suitable for } \\
\text { SRS that have mild problem in literacy. }\end{array}$ & $\begin{array}{l}\text { Follows the Pemulihan } \\
\text { syllabus as guideline. }\end{array}$ \\
\hline
\end{tabular}

\section{CONCLUSION AND FUTURE WORK}

In this study, M2M was developed for slow reading student as one of the teaching aid material to help teacher at school. It uses Malay Language as a main language in order to ensure the questions are well understood. It consists of five modules. This study was conducted to determine its usability via heuristic evaluation. A set of 17 customized heuristics that belongs to game heuristics and BBL heuristics were used to evaluate the games application. The evaluation result revealed that most of the questionnaire domains score as average and above average and earned good rating in many aspects assessed. Two questionnaire domains in game heuristics were rated low by users. This implies that the design of the games should be improved to ensure that it maximally supports students' learning. Meanwhile, the evaluation result revealed that all of the questionnaire domains in BBL heuristic score above average in all aspects assessed. This implies that BBL approaches are acceptable and can help to fully optimize SRS brain to enhance SRS literacy skills. The result of the heuristic evaluation also revealed the strengths and weaknesses of the games apps.
Besides, the evaluators also provide a positive feedbacks and comments. Those evaluation and feedback from the experts are essentials to further improve the application in order to meets the user requirement and expectation. The comments of the teacher users focused more on the content and enhancement of features that will suit SRS. Meanwhile, the comments from developer user focused more on the enhancement of features that will make the system complete.

There may be some possible limitations in this study. This study is focused on SRS but this evaluation not involved them as it is difficult for the SRS to understand the questions. The teachers involved also only for LINUS and Pemulihan teachers as they know the needs and requirements of SRS. SRS can only be involved with qualitative data collection because of their lack of understanding in written instructions if quantitative studies are carried out.

In future work, the improvements of M2M apps will be carried out and usability testing conducted in order to get real and reliable result. Once its' validity and reliability is tested in real population, M2M can be used commercially to SRS.

\section{ACKNOWLEDGMENT}

The authors would like to thank Sekolah Kebangsaan Bebuloh, W.P Labuan. The Ministry of Higher Education for the finance sponsored under program MyBrain15 (MyPhD). The Faculty of Information Science and Technology, Universiti Kebangsaan Malaysia for providing facilities and financial support under the university Grant with Project Number KRA-2018-025.

\section{REFERENCES}

[1] R. Jamian, "Permasalahan Kemahiran Membaca Dan Menulis Bahasa Melayu Murid-Murid Sekolah Rendah Di Luar Bandar," J. Pendidik. Bhs. Melayu, vol. 1, no. Bil. 1 (Mei 2011), pp. 1-1, 2011.

[2] M. Sanai, "Celik Huruf: Lancar Baca," in Buku Koleksi Kertas Kerja Seminar Penyelidikan IPGM KBL, 2009, pp. 102-112.

[3] A. Zain, "Penggunaan Bacaan Berulang Dapat Mempertingkatkan Kelancaran dan Kefahaman Dalam Kalangan Kanak-kanak Prasekolah," Proc. 4th Int. Conf. Teach. Educ. Join Conf. UPI UPSI Bandung, Indones. 8-10 Novemb, November, pp. 311-320, 2010.

[4] E. N. King, "Why is My Child Struggling to Read?," 2019. [Online]. Available: http://schoolpsychologistfiles.com/skills-needed-in-reading/. [Accessed: 28-Feb-2019].

[5] S. R. Zainal Abidin, S. F. Mat Noor, and N. Sahari, "Guidelines of Brain-based Learning through Serious Game for Slow Reader Students," in 2017 6th International Conference on Electrical Engineering and Informatics (ICEEI), 2017.

[6] R. R. Borah, "Slow Learners: Role of Teachers and Guardians in Honing their Hidden Skills," Int. J. Educ. Plan. Adm., vol. 3, no. 2, pp. 139-143, 2013.

[7] N. Abdollah, W. F. Wan Ahmad, and E. A. Patah Akhir, "Multimedia Design and Development in 'Komputer Saya' Courseware for Slow Learners," in Second International Conference on Computer Research and Development, 2010, pp. 354-358.

[8] J. L. Madtha, "Motivation And Encouragement In Teaching Slow Learners," Int. J. Curr. Res., vol. 7, no. 4, pp. 14643-14644, 2015.

[9] S. Chauhan, "Slow Learners: Their Psychology And Educational Programmes," Int. J. Multidiscip. Res., vol. 1, no. 8, pp. 279-289, 2011.

[10] S. R. Zainal Abidin, S. F. Mat Noor, and N. Sahari, "Low-fidelity Prototype Design for Serious Game for Slow-reading Students," Int. J. Adv. Comput. Sci. Appl., vol. 10, no. 3, pp. 270-276, 2019.

[11] Y. Zhonggen, "A Meta-Analysis of Use of Serious Games in Education over a Decade,” Int. J. Comput. Games Technol., no. 3, 2019. 
[12] M.-A. Maheu-Cadotte, S. Cossette, V. Dubé, G. Fontaine, T. Mailhot, P. Lavoie, A. Cournoyer, F. Balli, and G. Mathieu-dupuis, "Effectiveness of serious games and impact of design elements on engagement and educational outcomes in healthcare professionals and students: a systematic review and meta- analysis protocol," 2018.

[13] W. F. Wan Ahmad, M. N. Shahrina, and M. S. Nor Syafiza, "Development of a Multimedia Courseware for Slow Learner Children with Reading Difficulties: MyLINUS," in Advances in Visual Informatics. IVIC, pp. 371-382, 2013.

[14] R. N. Caine and G. Caine, Making Connections: Teaching and the Human Brain., no. 218. 1991.

[15] E. Jensen, "Brain-Based Learning: The New Paradigm of Teaching," Corwin Press, 2008.

[16] S. Saleh and A. D. Halim, "Kecenderungan Otak dan Hubungannya dengan Pencapaian dan Motivasi Pelajar," J. Pendidik. Malaysia, vol. 41, no. 1, pp. 65-70, 2016.

[17] K. Squire and H. Jenkins, "Harnessing the power of games in education," Insight, vol. 3, pp. 5-33, 2003.

[18] F. Fazil and S. Saleh, "Keberkesanan Pendekatan Pengajaran Berasaskan Otak Dalam Meningkatkan Kefahaman Pelajar Tingkatan Empat Terhadap Pembelajaran Konsep Dan Mekanisme Fotosintesis," Asia Pacific J. Educ. Educ., vol. 31, pp. 69-83, 2016.

[19] A. K. A. Bawaneh, A. N. M. Zain, and M. Ghazali, "The Effectiveness of Conflict Maps and the V-Shape Teaching Method in Science Conceptual Change among Eighth-Grade Students in Jordan," Int. Educ. Stud., vol. 3, no. 2, pp. 96-108, 2010.

[20] H. She, "Promoting Students' Learning of Air Pressure Concepts: The Interrelationship of TeachingApproaches and Student Learning Characteristics," J. Exp. Educ., vol. 7, no. 1, pp. 29-51, 2012.

[21] S. Saleh, "The Effectiveness of the Brain Based Teaching Approach in Enhanching Scientific Understanding of Newtonian Physics among Form Four Students," Int. J. Environ. Sci. Educ., vol. 7, no. 1, pp. 107$122,2012$.

[22] C. L. Weitze, "Developing Goals and Objectives for Gameplay and Learning," 2014.

[23] S. Saleh, "Keberkesanan Pendekatan Pengajaran Berasaskan Otak Dalam Menangani Masalah Berkaitan Motivasi Belajar Fizik Pelajar," in Prosiding Seminar Jawatankuasa Penyelarasan Pendidikan Guru, 2008.

[24] M. Rajanen, "Heuristic evaluation in game and gamification development," in GamiFIN Conference Pori, Finland, pp. 159-168, 2018.

[25] ISO/IEC 9126, "Quality Characteristics and Guidelines for the User," Int. Organ. Stand., p. 9241, 2001.

[26] W. I. Wan Malini, W. S. Syadiah Nor, N. M. Nik Siti Fatima, M. Mokhairi, M. Fatma Susilawati, and H. Rohayah, "Heuristic Evaluation Of i-Dyslex Tool for Dyslexia Screening," J. Telecommun. Electron. Comput. Eng.,vol. 9, no. 2, pp. 15-19, 2017.

[27] J. A. Borges, I. Morales, and N. J. Rodriguez, "Guidelines for Designing Usable World Wide Web Pages," in CH1'96 Companion, Vancouver, BC Canada, 1996, pp. 277-278.

[28] R. A. Moftah, P. Plasmann, A. M. Maatuk, and S. Aljawarneh, "An Overview about the Polymorphic Worms Signatures," in ICEMIS '15, September, Istanbul, Turkey, 2015, pp. 24-26.

[29] E. T. Hvannberg, E. L. Law, and M. K. Larusdottir, "Heuristic evaluation: Comparing ways of finding and reporting usability problems," Interact. Comput., vol. 19, pp. 225-240, 2007.
[30] M. Allen, L. M. Currie, S. Bakken, V. L. Patel, and J. J. Cimino, "Heuristic evaluation of paper-based Web pages: A simplified inspection usability methodology," ournal Biomed. Informatics, vol. 39, pp. 412-423, 2006.

[31] J. Nielsen and R. Molich, "Heuristic Evaluation of User Interface," in CHI '90 Proceedings of the SIGCHI Conference on Human Factors in Computing Systems, 1990, no. April, pp. 249-256.

[32] J. Nielsen, Usability Engineering. Boston: Academic Press., 1993.

[33] N. Schaffer, "Heuristic evaluation of games.," in Game usability-Advice from the experts for advancing the player experience (pp., Burlington, MA, USA, 2008, pp. 79-90.

[34] H. Desurvire and M. S. El-Nasr, "Graphically Speaking," Comput. Graph. Appl. IEEE, vol. 33, no. 4, pp. 82-87, 2013.

[35] J. Nielsen, "Enhancing the Explanatory Power of Usability Heuristics," in CHI '94 Proceedings of the SIGCHI Conference on Human Factors in Computing Systems, 1994, pp. 152-158.

[36] M. Penha, W. F. Marques Correia, F. F. da Costa Campos, and M. Lima Neves Barros, "Heuristic Evaluation of Usability - a Case study with the Learning Management Systems ( LMS ) of IFPE," Int. J. Humanit. Soc. Sci., vol. 4, no. 6, pp. 295-303, 2014.

[37] M. Hasiah and J. Azizah, "Heuristics Evaluation in Computer Games," in International Conference on Information Retrieval \& Knowledge Management (CAMP), 2010, pp. 188-193.

[38] D. Alonso-ríos, E. Mosqueira-rey, and V. Moret-bonillo, "A Systematic and Generalizable Approach to the Heuristic Evaluation of User Interfaces," Int. J. Human-Computer Interact., pp. 1-14, 2018.

[39] R. Geng and J. Tian, "Improving Web Navigation Usability by Comparing Actual and Anticipated Usage," IEEE Trans. HumanMachine Syst. •, vol. 45, no. 1, 2016.

[40] R. Y. Gómez, D. C. Caballero, and J. Sevillano, "Heuristic Evaluation on Mobile Interfaces : A New Checklist," ?e Sci. World J., vol. 2014, 2014.

[41] L. Hasan, "Heuristic Evaluation of Three Jordanian University Websites," Informatics Educ., vol. 12, no. 2, pp. 231-251, 2013.

[42] S. Noraidah, M. Hazura, and M. J. Hairulliza, "Pemeriksaan Pakar terhadap Kebolehgunaan Muzium Maya," in Kelestarian Warisan Budaya Melalui Teknologi Maklumat dan Komunikasi hlm, 2016, pp. $48-64$.

[43] A. Sivaji and S. Soo, "Enhancing the heuristic evaluation (HE) by development and validation of a collaborative design measurement system (CDMS): Collaborative design and measurement system for designers and testers," in 2012 IEEE Colloquium on Humanities, Science and Engineering (CHUSER), Kota Kinabalu, 2012, no. December, pp. 473-478.

[44] J. Nielsen, "Finding Usability Problems Through Heuristic Evaluation," in Proceedings of the SIGCHI Conference on Human Factors in Computer Systems, (CHI'92), Bauersfeld, P., Bennett, J., and Lynch, G., Eds. ACM, New York, NY., 1992, pp. 373-380.

[45] C. Barnum, N. Bevan, G. Cockton, J. Nielsen, J. Spool, and D. Wixon, "The 'Magic Number 5 ': Is It Enough for Web Testing ?," CHI 2003, Ft. Lauderdale, Florida, USA., no. 5, pp. 5-7, 2003.

[46] J. Nielsen and T. K. Landauer, "Model of the Finding of Usability Problems," in Proceedings of the INTERACT'93 and CHI'93 Conference on Human Factors in Computer Systems, Ashlund, S., Mullet, K., Henderson, A., Hollnagel, E., and White, T., Eds. ACM, New York, NY., 1993, pp. 206-213. 
APPENDIX A

\section{Visibility of system status}

- Does the application include a visible title page, section or site?

- Does the user always know where it is located?

- Does the user always know what the application is doing?

\section{Match between system and real world}

- Does information appear in a logical order for the user?

- Does the design of the icons correspond to everyday objects?

- Does every icon do the action that you expect?

- Does the application use phrases and concepts familiar to the user?

\section{User control and freedom}

- Is there a link to come back to initial state or homepage?

- Are the functions "undo" and "re-do" implemented?

- Is it easy to come back to an earlier state of the application?

\section{Consistency and standards}

- Do link labels have the same names as their destinations?

- Do the same actions always have the same results?

- Do the icons have the same meaning everywhere?

- Is the information displayed consistently on every page?

- Are the colors of the links standard? If not, are they suitable for its

use?

- Do navigation elements follow the standards? (Buttons, check box, ...)

\section{Error prevention}

- Does a confirmation message appear before taking the action?

- Is it clear what information needs to be entered in each box on a form?

- Does the search engine tolerate typos and spelling errors?

\section{Recognition rather than recall}

- Is it easy to use the application for the first time?

- Can you use the application at all times without remembering previous screens?

- Is all content needed for navigation or task found in the "current screen"?

- Is the information organized according to logic familiar to the end user?

\section{Flexibility and efficiency of use}

- Is it possible to easily perform an action done earlier?

- Does the design adapt to the changes of screen resolution?

- Is the use of accelerators visible to the normal user?

- Does it always keep the user busy? (without unnecessary delays)

\section{Aesthetic and minimalist design}

- Is used a design without redundancy of information?

- Is the information short, concise and accurate?

- Is each item of information different from the rest and not confused?

- Is the text well organized, with short sentences and quick to interpret?

\section{Help users recognition, diagnose and recover from errors}

- Does it display a message before taking irreversible actions?

- Are errors shown in real time?

- Is the error message that appears easily interpretable?

\section{Help and documentation}

- Is there the "help" option?

- Is there a section of frequently asked questions (FAQ)?

- Is the help documentation clear, with examples? 
APPENDIX B

Activation

- Is a different learning approach like serious game can give an active environment in a classroom setting?

- By using this application, the purpose in my classroom to create a supportive, challenging, and complex environment where questions are encouraged is achieved.

- I can see the positives changes of my students behavior and performance while using this application

Clarify the outcomes that need to be achieved and the learning process involved

- The objective been preview to students so that they know briefly what they learnt that day.

- This application easier for learning process takes place.

Making connection

- The topic is related with another?

- My students can't answer the right question if they skip one topic

\section{Carry out learning activities}

- I utilize some form of brain-based learning strategy (e.g. students: drawings, charts, lists, dialogues, actions, demonstrations, debates, or mind-maps) on a weekly basis.

- When playing an application, it give an opportunity for relax alertness learning environment which eliminated fears in the learner, while maintaining a highly challenging learning environment.

Demonstrating student's understanding

- This application is provided all the activities and exercise needed to achieved the learning objectives.

- I feel that how one learns, plays an important role in classroom learning.

\section{Review for students' retention}

- Is this application allowing students to choose any topic to learn?

- This game is enjoyable and can be repeating by students.

\section{Preview the next topic}

- This application pre-exposes my students to content $\&$ context of a topic before introducing it?

- Showing what to learn help in reducing the fear and undesirable attitude and motivation amongst students taught. 